\title{
ELŐTERJESZTÉS A MAGYAR TUDOMÁNYOS AKADÉMIA 190., RENDKÍVÜLI KÖZGYŰLLÉSE RÉSZÉRE 2018. DECEMBER 6.
}

\section{MOTION TO THE $190^{\text {TH }}$ EXTRAORDINARY GENERAL ASSEMBLY OF THE HUNGARIAN ACADEMY OF SCIENCES ON 6 DECEMBER 2018}

A Magyar Tudományos Akadémia Köztestülete mindent megtesz a hazai innováció, alkalmazott és alapkutatások színvonalának további emelésére, melynek legfontosabb alapfeltétele a nemzetközi színvonalú, hosszú távon tervező kutatói, fejlesztői, technikusi és oktatói személyi állomány elkötelezettségének biztosítása. Ezt a kormány 2018-as intézkedései veszélyeztetik.

Kérem a Közgyülést az alábbi felterjesztés megszavazására.

„A Közgyülés támogatja az innováció és a tudományos kutatások hatásfokának növelését, egyben elutasítja a Kormány azon módszereit, amelyek ezt veszélyeztetik, aláássák a kutatók jövőképét, bizonytalanságot és a tudományos értékrend felfüggesztését okozzák."'

Dr. Somogyi Péter

professzor az MTA rendes tagja

The Extraordinary General Assembly gives its support to improving the efficacy of innovation and research, and at the same time rejects the methods of the government, which have put this at risk by undermining the trust of scientists in their future, have caused uncertainty and have abandoned scientific values.

Peter Somogyi

FRS, FMedSci, Professor of Neurobiology Department of Pharmacology, University of Oxford, Oxford, United Kingdom

${ }^{1}$ Az MTA 190., rendkívüli közgyűlése 232 igen (61,2\%), 100 nem (26,4\%) és 47 érvénytelen $(12,4 \%)$ szavazattal elfogadta december 3-án szabályosan leadott egyéni előterjesztésemet. 